\title{
Loss of heterozygosity for chromosomal regions 15q14-21.1, 17q21.31, and 13q12.3-13.1 and its relevance for prostate cancer
}

\author{
Maria Nowacka-Zawisza ${ }^{1}$ Ewa Forma ${ }^{1} \cdot$ Maciej Walczak $^{1} \cdot$ Waldemar Różański $^{2}$. \\ Magdalena Bryś $^{1}$ - Wanda M. Krajewska ${ }^{1}$
}

Received: 23 September 2015/Accepted: 24 September 2015/Published online: 3 October 2015

(C) The Author(s) 2015. This article is published with open access at Springerlink.com

\begin{abstract}
Although prostate cancer is one of the most common cancers in men, the genetic defects underlying its pathogenesis remain poorly understood. DNA damage repair mechanisms have been implicated in human cancer. Accumulating evidence indicates that the fidelity of the response to DNA double-strand breaks is critical for maintaining genome integrity. RAD51 is a central player in double-strand break repair via homologous recombination, and its alterations may confer and increase the risk of cancer. RAD51 functioning depends on the indirect or direct interactions with BRCA1 and BRCA2. To evaluate the contribution of RAD51 to sporadic prostate cancer, loss of heterozygosity (LOH) for chromosomal region 15q1421.1 (RAD51 locus) was determined and compared to LOH in 17q21.31 (BRCAl locus) and 13q12.3-13.1 (BRCA2 region). DNA was isolated from prostate biopsies and matched peripheral blood of 50 patients. The regions 15q14-21.1, 17q21.31, and 13q12.3-13.1 were examined using microsatellite markers on chromosome 15 (D15S118, D15S214, D15S1006), chromosome 17 (D17S855, D17S1323), and chromosome 13 (D13S260, D13S290), respectively. The $\mathrm{LOH}$ in tumors was analyzed by PCR with fluorescently labeled primers and an ABI PRISM 377 DNA Sequencer. Allele sizing was determined by GeneScan version 3.1.2 and Genotyper version 2.5 software (Applied Biosystems, USA). LOH was identified in 57.5,
\end{abstract}

Maria Nowacka-Zawisza

mnz@biol.uni.lodz.pl

1 Department of Cytobiochemistry, Faculty of Biology and Environmental Protection, University of Lodz, Pomorska St. 141/143, 90-236 Lodz, Poland

2 2nd Department of Urology, Medical University of Lodz, Pabianicka 62, 93-513 Lodz, Poland
23, and $40 \%$ for chromosomal regions 15q14-21.1, 17q21.31, and 13q12.3-13.1, respectively. Twenty-six percent of studied cases manifested $\mathrm{LOH}$ for at least one marker in 15q14-21.1 exclusively. A significant correlation was found between LOH for studied region and PSAD (prostate-specific antigen density). The findings suggest that $R A D 51$ may be considered as a prostate cancer susceptibility gene.

Keywords Loss of heterozygosity (LOH) - Prostate cancer $\cdot$ RAD51 - Molecular markers

\section{Introduction}

Prostate cancer is the second most common cancer to affect males worldwide. This tumor is one of the most frequently registered cancers among men in Poland, and cases of prostate cancer represent above $14 \%$ of all cancer morbidity and $8 \%$ of cancer mortality among men [1]. As prostate cancer exhibits a diverse spectrum of behavior, management of the disease is controversial [2]. Prostatespecific antigen (PSA) is considered to be the most remarkable prostate tumor marker. However, there is no clear evidence of a relationship between mean PSA levels at screening and the incidence or the rate of cancer detection. Hence, improved biomarkers are needed to enhance prediction of PSA. Various candidates have been proposed to increase the value of PSA as a diagnostic and prognostic marker [3-8]. However, unlike some human malignancies, the etiology of prostate cancer does not appear to be associated with a specific genetic susceptibility but rather with multiple gene loci, each independently conferring a low but cumulative risk. Meta-analysis and genome-wide association studies (GWAS) have 
mapped the loci for prostate cancer susceptibility to several chromosomes, and although putative candidate genes have also been suggested, their significance for prostate cancer remains unknown $[9,10]$.

Numerous studies describe an association between mutations in DNA repair genes and neoplastic transformation. Mutations in BRCA1, BRCA2, BRIPI/FANCCJ, CHEK2, MMR, and NBS1 have been found to confer an increased risk of prostate cancer [11-20]. The response of cells to DNA damage and their ability to maintain genomic stability by DNA repair are critical for preventing cancer initiation and progression. The most dangerous class of genetic material damage is the double-strand break (DSB). The key mode of DNA double-strand break repair includes homologous recombination (HR), which precisely restores the genomic sequence of the broken DNA ends by using sister chromatids as a template for repair [21-23].

Although a plethora of proteins participate in the HR repair of double-strand breaks, a crucial role is played by RAD51, a mammalian homolog of bacterial RecA, an evolutionarily conserved recombinase encoded by the RAD51 gene located on human chromosome 15q15.1. RAD51 co-localizes with BRCA1 and BRCA2 protein within nuclear foci in mitotic cells. The foci have been observed to contain BRCA1 together with the BRCA1binding protein BARD1, both before and after DNA damage. RAD51 foci appear during the S-phase and are required to initiate stalled or broken DNA replication forks. RAD51 recombinase forms a direct association with BRCA2, which is essential for normal recombination and genome stability, as the interaction between BRCA2 and RAD51 is fundamental for error-free HR in response to DSBs. While BRCA2 is directly involved in RAD51-mediated repair, BRCA1 acts upstream from this pathway and is thought to be required for the transport of RAD51 from the cytoplasm into the nucleus and sites of DNA damage. BRCA2 contains nuclear localization signals not found in RAD51, supporting the notion that BRCA2 also facilitates RAD51 transport into the nucleus. The direct interactions of RAD51 and BRCA1 have not yet been fully elucidated, despite gene expression profiling and network modeling revealing a complex heterogeneity in the mechanisms of BRCA1 involvement in tumorigenesis [24, 25].

The limited understanding of the genetic elements governing prostate cancer progression demands further studies of its predisposing genes. Since genome instability is a hallmark of a malignant phenotype and a driving force for tumorigenesis, investigations of genes involved in DNA double-strand breaks merit special interest. Although germline mutations and $\mathrm{LOH}$ in $B R C A 1$ and $B R C A 2$ genes have been detected in mutation carriers, no data currently exist concerning the role of $R A D 51$ in sporadic prostate cancer $[26,27]$. Hence, the aim of the present study is to determine whether loss of heterozygosity (LOH) in RAD51, $B R C A 1$, and BRCA2 contributes to the sporadic prostate cancer. Loss of heterozygosity for chromosomal regions 15q14-21.1, 17q21.31, and 13q12.3-13.1 was assessed by seven microsatellite markers. The relationships between the clinicopathological parameters of prostate adenocarcinoma and LOH in studied chromosomal regions were examined.

\section{Patients and methods}

\section{Patients and tissue samples}

Peripheral blood and prostate adenocarcinoma biopsies were collected at the Second Department of Urology, Medical University of Lodz, Poland, between October 2009 and December 2011. All samples were obtained from the peripheral zone of the prostate gland in patients who underwent transrectal ultrasound (TRUS)-guided prostate biopsy. After (TRUS)-guided prostate biopsy, the tissue samples were placed in RNAlater ${ }^{\circledR}$ solution (Qiagen, Inc., Chatsworth, CA, USA) and stored at $-70{ }^{\circ} \mathrm{C}$ until further analysis. Blood samples from each patient were collected on EDTA and frozen.

All tumor specimens were routinely assessed clinicopathologically for cancer stage and Gleason score by independent pathologists. All other data were taken from patients by diagnostic and epidemiology questionnaires. The following characteristics were recorded: age of patients, the level of prostate-specific antigen PSA, i.e., total PSA (PSAT) and free PSA (PSAF) in the serum of patients measured at the time of diagnosis, and PSA density (PSAD) for tumor tissue and prostate volume. None of the patients had undergone hormonal therapy, radiotherapy, or chemotherapy prior to surgery. Samples were obtained in accordance with ethical and legal requirements. Informed consent was obtained from patients, and the Independent Ethical Committee of the Medical University of Lodz, Poland, approved this study (RNN/59/09/KE).

In total, 50 patients with prostate adenocarcinoma were recruited for this study. The clinical characteristics of the studied material are given in Table 1.

\section{DNA isolation}

The DNA from prostate biopsies was isolated using TRI Reagent ${ }^{\circledR}$ (Sigma-Aldrich, USA). The DNA from peripheral blood of patients with prostate adenocarcinoma was isolated using AxyPrep ${ }^{\mathrm{TM}}$ Blood Genomic DNA Miniprep Kit (Axygen, USA) as a reference. DNA purity and quantity were estimated by UV spectroscopy (Eppendorf BioPhotometer TM Plus, Eppendorf, Germany). DNA was identified by a ratio of $260 / 280 \mathrm{~nm}$ ranged $1.8-2.0$. 
Table 1 Clinical characteristics of study subjects

\begin{tabular}{|c|c|}
\hline \multicolumn{2}{|l|}{ Age (year) } \\
\hline Range & $55-86$ \\
\hline Mean \pm SD & $71.2 \pm 8.6$ \\
\hline Median & 72 \\
\hline$<72$ & $24(48 \%)$ \\
\hline$\geq 72$ & $26(52 \%)$ \\
\hline \multicolumn{2}{|l|}{ PSAT (ng/ml) } \\
\hline Range & $4.58-1489$ \\
\hline Mean \pm SD & $104.04 \pm 251.28$ \\
\hline Median & 17.37 \\
\hline$\geq 4-10$ & $15(30 \%)$ \\
\hline$\geq 10-20$ & $11(22 \%)$ \\
\hline$>20$ & $24(48 \%)$ \\
\hline \multicolumn{2}{|l|}{ PSAF/PSAT } \\
\hline Range & $0.05-0.79$ \\
\hline Mean \pm SD & $0.19 \pm 0.13$ \\
\hline Median & 0.16 \\
\hline$<0.16$ & $24(48 \%)$ \\
\hline$\geq 0.16$ & $26(52 \%)$ \\
\hline \multicolumn{2}{|l|}{ PSAD (ng/ml) } \\
\hline Range & $0.08-56.4$ \\
\hline Mean \pm SD & $2.72 \pm 8.51$ \\
\hline Median & 0.29 \\
\hline$<0.15$ & $8(16 \%)$ \\
\hline$\geq 0.15$ & $42(84 \%)$ \\
\hline \multicolumn{2}{|c|}{ Prostate volume $(\mathrm{ml})$} \\
\hline Range & $20.7-191$ \\
\hline Mean \pm SD & $57.72 \pm 35.91$ \\
\hline Median & 47.25 \\
\hline$<50$ & $28(56 \%)$ \\
\hline$\geq 50$ & $22(44 \%)$ \\
\hline \multicolumn{2}{|l|}{ Gleason score } \\
\hline 4 & $2(4 \%)$ \\
\hline 6 & $9(18 \%)$ \\
\hline 7 & $18(36 \%)$ \\
\hline 8 & $11(22 \%)$ \\
\hline 9 & $9(18 \%)$ \\
\hline 10 & $1(2 \%)$ \\
\hline \multicolumn{2}{|l|}{ Cancer stage } \\
\hline $\mathrm{T} 1$ & $12(24 \%)$ \\
\hline $\mathrm{T} 2$ & $14(28 \%)$ \\
\hline $\mathrm{T} 3$ & $12(24 \%)$ \\
\hline $\mathrm{T} 4$ & $12(24 \%)$ \\
\hline
\end{tabular}

\section{PCR conditions and primers}

Genetic alterations for chromosomal regions: 15q14-21.1, 17q21.31, and 13q12.3-13.1 were analyzed for seven microsatellite markers. Information about the microsatellite markers and the sequences for all the primers for $\mathrm{LOH}$ analysis was obtained from the National Center for Biotechnology Information-NCBI (www.ncbi.nlm.nih. gov). The primers were synthesized and labeled fluorescently by Applied Biosystems (USA). Polymerase chain reaction (PCR) was carried out in a $10 \mu \mathrm{l}$ reaction volume containing 50 ng genomic DNA, $1 \times$ Solis Biodyne Buffer B1, 3U HOT FIREPol ${ }^{\circledR}$ DNA polymerase, $200 \mu \mathrm{l}$ GeneAmpdNTP Mix, $2 \mathrm{mM} \mathrm{MgCl}_{2}$, and $10 \mathrm{pmol} / \mu \mathrm{l}$ primers, of which one was end-labeled with 6-FAM or TET phosphoramidite dye. PCR reagents were obtained from Solis Biodyne (Estonia) and Applied Biosystems (USA). Each microsatellite marker was amplified at its own specific annealing temperature to optimize the PCR reaction. Profile times and temperatures were as follows: $12 \mathrm{~min}$ at $95^{\circ} \mathrm{C} ; 30$ amplification cycles comprising denaturation for $15 \mathrm{~s}$ at $95{ }^{\circ} \mathrm{C}$, primer annealing for $30 \mathrm{~s}$ at $55^{\circ} \mathrm{C}$ (for microsatellite markers: D15S118, D15S214, D15S1006, D17S1323, D13S260) or $51{ }^{\circ} \mathrm{C}$ (for microsatellite markers D17S855, D13S290), elongation for $30 \mathrm{~s}$ at $72{ }^{\circ} \mathrm{C} ; 10 \mathrm{~min}$ for $72{ }^{\circ} \mathrm{C}$. Amplification was performed in a GeneAmp 2400 thermal cycler (PerkinElmer, USA). Localization of the analyzed microsatellite markers and primer sequences are presented in Table 2 .

\section{LOH analysis}

PCR products were electrophoresed on polyacrylamide gel (5\% Long Ranger) containing $6 \mathrm{M}$ urea and $1 \times \mathrm{TBE}$ $(10 \times$ TBE: Tris borate, EDTA, pH 8.0). After PCR, the samples were mixed with stop solution containing deionized formamide, GeneScan-350 TAMRA Size Standard, and loading buffer (blue dextran, EDTA), denatured, and chilled on ice. Three microliters of each sample mixture was applied in each well and run on an ABI PRISM 377 DNA Sequencer (Applied Biosystems, USA). The data were collected automatically. Allele sizing was determined by GeneScan v. 3.1.2 and Genotyper v. 2.5 software (Applied Biosystems, USA). Amplification of microsatellite markers will yield one or two major allele peaks, depending upon whether the individual is homozygous (non-informative cases) or heterozygous (informative cases) for that marker. LOH was defined as loss or $\geq 50 \%$ reduction in either allele in cancer compared with peripheral blood derived from the same patient. Allele ratios were calculated for informative cases as described by Cawkwell et al. [28] according to the formula $\mathrm{T} 1 \times \mathrm{N} 2 / \mathrm{T} 2 \times \mathrm{N} 1$, where $\mathrm{T} 1$ and $\mathrm{N} 1$ are the values of the shorter length allele and $\mathrm{T} 2$ and $\mathrm{N} 2$ of the longer length allele for the tumor (T) and normal (N) sample, respectively. A representative sample with LOH in D15S118 and D15S214 microsatellite markers for $15 \mathrm{q} 14-21.1$ region in prostate cancer as compared to normal tissue is presented in Fig. 1. For each prostate cancer sample, fractional allele loss (FAL) index 
Table 2 Characteristics of the analyzed microsatellite markers and PCR reaction (http://www.ncbi.nlm.nih.gov)

\begin{tabular}{|c|c|c|c|c|c|}
\hline Microsatellite marker & Chromosomal region (gene) & Position & Primer sequence & Dye & Product sizes (bp) \\
\hline D15S118 & $15 q 14$ & 12996879 & $\begin{array}{l}\text { (+) TCAAAGACCCATATCAACCA } \\
(-) \text { GTGCTGAAAAGCGACACTTA }\end{array}$ & 6-FAM & $218-232$ \\
\hline D15S214 & $15 \mathrm{q} 15.1(R A D 51)$ & 17166170 & $\begin{array}{l}\text { (+) GGAGGGCACTTCCTGAG } \\
\text { (-) GCCTGGCATCACGACT }\end{array}$ & TET & $260-274$ \\
\hline D15S1006 & $15 q 21.1$ & 24439646 & $\begin{array}{l}\text { (+) AGGGAATACTTCAAAACTC } \\
\text { (-) CCACTTGGCTATGGTGAAT }\end{array}$ & 6-FAM & $212-224$ \\
\hline D17S855 & $17 \mathrm{q} 21.31(B R C A 1)$ & 37861601 & $\begin{array}{l}\text { (+) GGATGGCCTTTTAGAAAGTGG } \\
\text { (-) ACACAGACTTGTCCTACTGCC }\end{array}$ & 6-FAM & $142-156$ \\
\hline D17S1323 & & 37894900 & $\begin{array}{l}\text { (+) TAGGAGATGGATTATTGGTG } \\
\text { (-) AAGCAACTTTGCAATGAGTG }\end{array}$ & TET & $153-161$ \\
\hline D13S260 & 13q12-13 (BRCA2) & 13503800 & $\begin{array}{l}\text { (+) AGATATTGTCTCCGTTCCATGA } \\
\text { (-) CCCAGATATAAGGACCTGGCTA }\end{array}$ & 6-FAM & $155-171$ \\
\hline D13S290 & & 12495878 & $\begin{array}{l}(+) \text { CCTTAGGCCCCATAATCT } \\
(-) \text { CAAATTCCTCAATTGCAAAAT }\end{array}$ & TET & $176-190$ \\
\hline
\end{tabular}

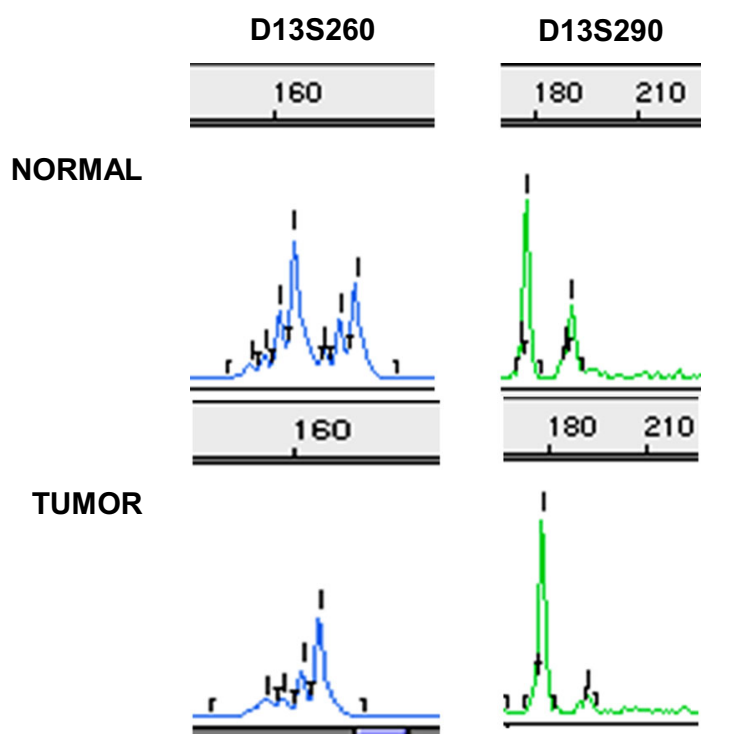

Fig. 1 Example of LOH analysis for 13q12-13 region in prostate cancer

was also calculated reflecting the ratio of total number of chromosomal loci with $\mathrm{LOH}$ to the total number of informative loci examined.

\section{Statistical analysis}

The statistical significance of $\mathrm{LOH}$ for at least one microsatellite marker identified concomitantly in three studied regions was tested using Spearman rank correlation test. Statistical significance of the relationship between the presence of $\mathrm{LOH}$ and clinicopathological parameters was performed using Fisher's exact test. $P<0.05$ was considered statistically significant. For associations between clinical variables of patients (age at diagnosis, total PSA (PSAT), total/free PSA value (PSAF/PSAT), PSA density (PSAD), prostate volume), histopathological parameters (according to TNM classification and Gleason score), and FAL index values, a Mann-Whitney $U$ test or KruskalWallis test was performed. The correlation between presence of LOH and the level of PSA and patients age was examined using linear regression. The statistical analysis was carried out using the Statistica for Windows, v. 5.

\section{Results}

The loss of heterozygosity ( $\mathrm{LOH}$ ) was evaluated using the microsatellite markers D15S118, D15S214, and D15S1006 for chromosomal region 15q14-21.1, D17S855, and D17S1323 for chromosomal region 17q21.31, and D13S260 and D13S290 for chromosomal region 13q12.3-13.1. The LOH studies rely on the detection of the loss of a single copy of the two alleles or $\geq 50 \%$ reduction in either allele. Those with detectable heterozygous alleles were defined as informative cases. Frequency of LOH for studied microsatellite markers in prostate cancer is presented in Table 3.

As shown in Table 4, genomic deletion detected by allelic loss varied according to the region tested. In the case of chromosomal region 15q14-21.1, loss of heterozygosity was observed in $57.5 \%$, i.e., in 23 out of 40 heterozygous patients. In the region 15q14-21.1, the highest incidence of $\mathrm{LOH}$, corresponding to $60 \%$ of informative cases, was found for microsatellite marker D15S214 located at RAD51 locus. In the $17 \mathrm{q} 21.31$ region, $\mathrm{LOH}$ occurred in $23 \%$, i.e., in 7 out of 30 heterozygous patients, and in the 13q12.313.1 region in $40 \%$, i.e., in 14 out of 35 heterozygous patients. Twenty-six percent of the studied prostate cancer 
Table 3 Frequency of LOH in prostate cancer for studied microsatellite markers

\begin{tabular}{|c|c|c|c|c|c|c|c|c|}
\hline Sample no. & D15S118 & D15S214 & D15S1006 & D17S855 & D17S1323 & D13S260 & D13S290 & FAL index \\
\hline 1 & ni & $\mathrm{ni}$ & ni & NG & NG & NG & ni & 0 \\
\hline 2 & $\mathrm{NG}$ & NG & NG & ni & NG & ni & NG & 0 \\
\hline 3 & ni & ni & ni & NG & $\mathrm{ni}$ & $\mathrm{LOH}$ & $\mathrm{LOH}$ & 0.667 \\
\hline 4 & $\mathrm{NG}$ & $\mathrm{LOH}$ & NG & ni & $\mathrm{ni}$ & ni & ni & 0.333 \\
\hline 5 & ni & $\mathrm{LOH}$ & NG & NG & $\mathrm{ni}$ & NG & NG & 0.5 \\
\hline 6 & ni & ni & NG & ni & ni & NG & $\mathrm{LOH}$ & 0.5 \\
\hline 7 & ni & $\mathrm{LOH}$ & ni & ni & NG & $\mathrm{ni}$ & ni & 0 \\
\hline 8 & $\mathrm{NG}$ & $\mathrm{LOH}$ & $\mathrm{LOH}$ & ni & NG & ni & ni & 0.667 \\
\hline 9 & ni & $\mathrm{ni}$ & NG & ni & ni & NG & ni & 0 \\
\hline 10 & NG & ni & ni & ni & ni & $\mathrm{ni}$ & NG & 0.5 \\
\hline 11 & $\mathrm{NG}$ & ni & ni & ni & ni & NG & ni & 0.667 \\
\hline 12 & ni & $\mathrm{LOH}$ & ni & ni & NG & $\mathrm{LOH}$ & ni & 1 \\
\hline 13 & NG & $\mathrm{NG}$ & ni & NG & ni & $\mathrm{LOH}$ & ni & 0.4 \\
\hline 14 & ni & ni & ni & NG & ni & ni & ni & 0.6 \\
\hline 15 & ni & ni & ni & NG & ni & ni & NG & 0.333 \\
\hline 16 & $\mathrm{NG}$ & ni & ni & ni & ni & ni & ni & 0.2 \\
\hline 17 & NG & ni & ni & ni & ni & $\mathrm{LOH}$ & ni & 0 \\
\hline 18 & ni & ni & $\mathrm{LOH}$ & ni & ni & $\mathrm{LOH}$ & ni & 1 \\
\hline 19 & $\mathrm{LOH}$ & $\mathrm{LOH}$ & ni & ni & NG & ni & ni & 0 \\
\hline 20 & ni & ni & ni & NG & ni & NG & ni & 0.5 \\
\hline 21 & ni & NG & ni & ni & ni & ni & $\mathrm{LOH}$ & 0 \\
\hline 22 & ni & ni & ni & ni & ni & NG & NG & 1 \\
\hline 23 & NG & $\mathrm{LOH}$ & ni & ni & NG & NG & ni & 0 \\
\hline 24 & $\mathrm{NG}$ & $\mathrm{LOH}$ & ni & ni & ni & $\mathrm{LOH}$ & ni & 0 \\
\hline 25 & $\mathrm{LOH}$ & $\mathrm{LOH}$ & ni & $\mathrm{LOH}$ & $\mathrm{ni}$ & $\mathrm{LOH}$ & ni & 0.75 \\
\hline 26 & NG & $\mathrm{LOH}$ & $\mathrm{ni}$ & ni & $\mathrm{ni}$ & $\mathrm{ni}$ & NG & 0 \\
\hline 27 & NG & ni & ni & $\mathrm{LOH}$ & NG & ni & ni & 0 \\
\hline 28 & $\mathrm{LOH}$ & $\mathrm{NG}$ & ni & $\mathrm{LOH}$ & ni & ni & ni & 0 \\
\hline 29 & ni & $\mathrm{LOH}$ & ni & ni & ni & $\mathrm{ni}$ & ni & 0.5 \\
\hline 30 & ni & ni & ni & NG & ni & ni & NG & 0.5 \\
\hline 31 & $\mathrm{LOH}$ & ni & ni & NG & $\mathrm{ni}$ & $\mathrm{LOH}$ & $\mathrm{LOH}$ & 0.5 \\
\hline 32 & $\mathrm{LOH}$ & ni & $\mathrm{LOH}$ & NG & $\mathrm{ni}$ & ni & ni & 0 \\
\hline 33 & $\mathrm{LOH}$ & NG & ni & ni & ni & ni & ni & 0.667 \\
\hline 34 & $\mathrm{LOH}$ & $\mathrm{LOH}$ & ni & NG & ni & NG & NG & 1 \\
\hline 35 & $\mathrm{LOH}$ & $\mathrm{NG}$ & ni & $\mathrm{LOH}$ & ni & NG & $\mathrm{LOH}$ & 0.75 \\
\hline 36 & ni & ni & ni & ni & ni & NG & NG & 0.25 \\
\hline 37 & NG & ni & ni & NG & NG & ni & ni & 0 \\
\hline 38 & NG & ni & ni & ni & NG & NG & $\mathrm{LOH}$ & 0 \\
\hline 39 & ni & ni & ni & ni & $\mathrm{LOH}$ & NG & ni & 0 \\
\hline 40 & ni & $\mathrm{LOH}$ & ni & ni & NG & ni & ni & 0.25 \\
\hline 41 & NG & $\mathrm{LOH}$ & NG & $\mathrm{LOH}$ & NG & NG & ni & 0 \\
\hline 42 & $\mathrm{ni}$ & NG & ni & ni & $\mathrm{ni}$ & NG & NG & 0.5 \\
\hline 43 & ni & NG & ni & NG & $\mathrm{ni}$ & NG & NG & 0.25 \\
\hline 44 & $\mathrm{ni}$ & $\mathrm{LOH}$ & ni & ni & ni & ni & ni & 0.333 \\
\hline 45 & ni & $\mathrm{NG}$ & $\mathrm{LOH}$ & ni & ni & NG & $\mathrm{LOH}$ & 0.333 \\
\hline 46 & $\mathrm{ni}$ & ni & NG & ni & $\mathrm{ni}$ & ni & ni & 0.667 \\
\hline 47 & ni & ni & ni & ni & $\mathrm{ni}$ & NG & NG & 0 \\
\hline 48 & $\mathrm{LOH}$ & ni & ni & NG & $\mathrm{LOH}$ & $\mathrm{Ni}$ & $\mathrm{LOH}$ & 0.667 \\
\hline
\end{tabular}


Table 3 continued

\begin{tabular}{lllllllll}
\hline Sample no. & D15S118 & D15S214 & D15S1006 & D17S855 & D17S1323 & D13S260 & D13S290 & FAL index \\
\hline 49 & ni & NG & NG & ni & NG & NG & ni & 0 \\
50 & ni & ni & NG & NG & NG & ni & NG & 0.333 \\
\hline
\end{tabular}

$\mathrm{LOH}$ loss of heterozygosity, $N G$ heterozygous without $\mathrm{LOH}, n i$ non-informative cases (homozygous)

Table 4 Incidence of LOH at 15q14-21.1, 17q21.31, and 13q12-13 chromosomal regions in prostate cancer

\begin{tabular}{llc}
\hline Chromosomal region & Number of informative case/studied cases $(\%)$ & Number of tumor with LOH/informative cases $(\%)$ \\
\hline $15 q 14-21.1$ & $40 / 50(80 \%)$ & $23 / 40(57.5 \%)$ \\
$17 q 21.31$ & $30 / 50(60 \%)$ & $7 / 30(23 \%)$ \\
$13 q 12.3-13.1$ & $35 / 50(70 \%)$ & $14 / 35(40 \%)$ \\
\hline
\end{tabular}

cases displayed $\mathrm{LOH}$ for at least one microsatellite marker at $15 \mathrm{q} 14-21.1$ region, without $\mathrm{LOH}$ in the $17 \mathrm{q} 21.31$ or 13q12.3-13.1 regions. The $\mathrm{LOH}$ for at least one microsatellite marker in the $17 \mathrm{q} 21.31$ and $13 \mathrm{q} 12.3-13.1$ regions, without $\mathrm{LOH}$ in 15q14-21.1 region, was estimated as only 6 and $19 \%$, respectively.
The association of the $\mathrm{LOH}$ in studied chromosomal regions with clinicopathological characteristics of patients was analyzed using Fisher's exact test. A significant correlation was found between $\mathrm{LOH}$ in chromosomal regions 15q14-21.1 and 13q12.3-13.1 and PSA density (PSAD) (Table 5).
Table 5 Relationship between $\mathrm{LOH}$ at $15 \mathrm{q} 14-21.1,17 \mathrm{q} 21.31$, and $13 q 12-13$ regions and the clinicopathological characteristics of prostate cancer

\begin{tabular}{|c|c|c|c|c|c|c|c|c|c|c|c|c|}
\hline \multirow[t]{3}{*}{ Clinical characteristics } & \multicolumn{12}{|c|}{ Chromosomal region } \\
\hline & \multicolumn{4}{|c|}{$15 q 14-21.1$} & \multicolumn{4}{|c|}{$17 q 21.31$} & \multicolumn{4}{|c|}{$13 q 12.3-13.1$} \\
\hline & $I$ & $N$ & $\mathrm{LOH}$ & $P$ & $I$ & $N$ & $\mathrm{LOH}$ & $P$ & $I$ & $N$ & $\mathrm{LOH}$ & $P$ \\
\hline Tumor cases & 40 & 17 & 23 & & 30 & 23 & 7 & & 35 & 21 & 14 & \\
\hline \multicolumn{13}{|l|}{ Age } \\
\hline$<72$ & 18 & 7 & 11 & 0.755 & 16 & 11 & 5 & 0.399 & 21 & 13 & 8 & $>0.999$ \\
\hline$\geq 72$ & 22 & 10 & 12 & & 14 & 12 & 2 & & 14 & 8 & 6 & \\
\hline \multicolumn{13}{|l|}{ PSAT (ng/ml) } \\
\hline$\geq 4-10$ & 14 & 6 & 8 & 0.088 & 8 & 7 & 1 & 0.284 & 11 & 5 & 6 & 0.383 \\
\hline$>10-20$ & 6 & 5 & 1 & & 5 & 5 & 0 & & 9 & 7 & 2 & \\
\hline$>20$ & 20 & 6 & 14 & & 17 & 11 & 6 & & 15 & 9 & 6 & \\
\hline \multicolumn{13}{|l|}{ PSAF/PSAT } \\
\hline$<0.16$ & 18 & 7 & 11 & 0.755 & 15 & 13 & 2 & 0.390 & 17 & 11 & 6 & 0.733 \\
\hline$\geq 0.16$ & 22 & 10 & 12 & & 15 & 10 & 5 & & 18 & 10 & 8 & \\
\hline \multicolumn{13}{|l|}{ PSAD (ng/ml) } \\
\hline$<0.15$ & 8 & 2 & 6 & 0.049 & 7 & 4 & 3 & 0.306 & 7 & 1 & 6 & 0.001 \\
\hline$\geq 0.15$ & 32 & 15 & 17 & & 23 & 19 & 4 & & 28 & 20 & 8 & \\
\hline \multicolumn{13}{|l|}{ Prostate volume $(\mathrm{ml})$} \\
\hline$<50$ & 22 & 11 & 11 & 0.348 & 14 & 11 & 3 & $>0.999$ & 21 & 16 & 5 & 0.033 \\
\hline$\geq 50$ & 18 & 6 & 12 & & 16 & 12 & 4 & & 14 & 5 & 9 & \\
\hline \multicolumn{13}{|l|}{ Gleason score } \\
\hline$<7$ & 15 & 7 & 8 & 0.749 & 6 & 4 & 2 & 0.603 & 10 & 6 & 4 & $>0.999$ \\
\hline$\geq 7$ & 25 & 10 & 15 & & 24 & 19 & 5 & & 25 & 15 & 10 & \\
\hline \multicolumn{13}{|l|}{ Cancer stage } \\
\hline $\mathrm{T} 1-\mathrm{T} 2$ & 21 & 8 & 13 & 0.749 & 13 & 11 & 2 & 0.427 & 19 & 11 & 8 & $>0.999$ \\
\hline T3-T4 & 19 & 9 & 10 & & 17 & 12 & 5 & & 16 & 10 & 6 & \\
\hline
\end{tabular}

$P<0.05$ indicates significant association, $I$ Informative cases, $N G$ heterozygous without LOH (negative cases) 


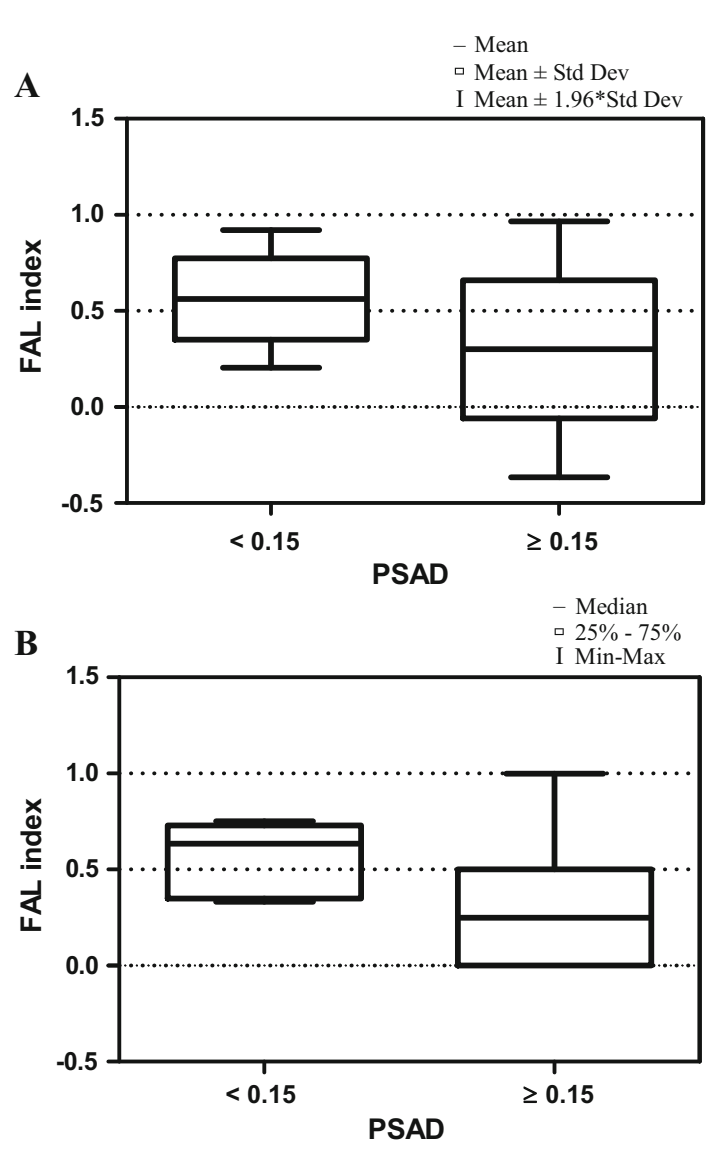

Fig. 2 Box-and-whisker plot, representing the $\mathbf{a}$ mean and $\mathbf{b}$ median FAL index values for the PSAD in prostate cancer

Mann-Whitney $U$ test revealed statistically significant differences between FAL index levels and PSA density (Fig. 2). There was no statistically significant correlation between FAL index levels and patients' age, free to total PSA value, prostate volume, Gleason score, and TNM classification (Mann-Whitney U test) as well as total PSA level (Kruskal-Wallis test). Neither correlation between age of patients with LOH and PSA level, free to total PSA value nor PSA density was identified (data not shown).

\section{Discussion}

Although the contribution of the homologous recombination mediators $B R C A 1$ and $B R C A 2$ to prostate cancer has been previously investigated, this is the first study to address the importance of RAD51 genetics in the occurrence of sporadic prostate cancer [26, 29]. RAD51 is a relatively small and rigid protein playing a basic role in the high-fidelity DNA repair mechanism of homologous recombination via homology search and DNA strand exchange. RAD51 appears vital for cell survival, as its depletion results in embryonic lethality. It has been highly conserved throughout evolution, and until now, no single mutation has been detected in the coding region of RAD51 in any type of cancer. However, a strong correlation has been identified between its expression level and both cancer development and progression. It is suggested that overexpression of RAD51 suppresses recombination defects [24, 30-32].

The progression of prostate cancer as in other malignancies is characterized by increased genetic and epigenetic aberrations. Of particular interest are germline polymorphisms and allelic imbalances, which may affect tumor suppressor genes and oncogenes [8, 33-35].

The BRCA1 and BRCA2 genes, whose best known function is concerned with the DNA damage response, have been reported to contribute to prostate cancer, although to different extents. The Breast Cancer Linkage Consortium report increased prostate cancer risk of BRCA1 mutation carriers below the age of 65 , with a relative risk of 1.82 , but no increase in those aged over 65 . For BRCA2 mutation carriers, the relative risk of developing prostate cancer was estimated as 4.65 , rising to 7.33 for men younger than 65 years [36-39]. Uchida et al. [40] identified $\mathrm{LOH}$ in the BRCAl gene in primary prostate cancer using seven highly polymorphic tandem repeat markers on chromosome $17 \mathrm{q} 21$, in addition to an analysis of the whole coding region of the BRCAl gene. Four of the 24 prostate cancer specimens revealed the presence of $\mathrm{LOH}$ at one or more loci, all of which were found to be at stage D with poor histological differentiation. One of the 24 cases showed a germline mutation of the $B R C A l$ gene. Willems et al. [41] observed $\mathrm{LOH}$ at $B R C A 2$ in 10 of 14 tumors from $B R C A 2$ mutation carriers $(71 \%)$, but no $\mathrm{LOH}$ in $B R C A 1$ in four tumors from BRCAl mutation carriers. Assuming that $\mathrm{LOH}$ occurs only because the cancer is caused by the germline mutation, carriers of BRCA2 mutations are at 3.5-fold increased risk of prostate cancer. Similarly Edwards et al. [37] identified $\mathrm{LOH}$ in the majority of tumors of $B R C A 2$ mutation carriers. On the other hand, Willems-Jones et al. [42] note that high-grade prostatic intraepithelial neoplasia, believed to be a precursor to prostate adenocarcinoma in some cases, does not display $\mathrm{LOH}$ at the mutation locus in BRCA2 mutation carriers with aggressive prostate cancer.

The present study reveals in prostate cancer the presence of $\mathrm{LOH}$ in $57.5,23$, and $40 \%$ for chromosomal regions 15q14-21.1, 17q21.31, and 13q12.3-13.1, respectively. In the region $15 \mathrm{q} 14-21.1$, the highest incidence of LOH corresponding to $60 \%$ was found for microsatellite marker D15S214 located at RAD51 locus. Hence, chromosomal region 15q14-21.1 was found to display a higher incidence of LOH than BRCA loci, especially BRCA2, which is considered a prostate tumor suppressor. In prostate cancer, $26 \%$ of cases manifested $\mathrm{LOH}$ at 15q14-21.1 chromosomal 
region exclusively, without $\mathrm{LOH}$ in the $17 \mathrm{q} 21.31$ or $13 q 12.3-13.1$ regions. Interestingly, $\mathrm{LOH}$ in $15 q 14-21.1$ chromosomal region appeared to be related to PSA density.

\section{Conclusions}

The high frequency of allelic losses at the RAD51 locus indicates the important role played by this gene in prostate cancer and sheds light on the novel perspective of genetic changes associated with its development. RAD51 displayed a higher incidence of LOH than BRCA2, which is considered a prostate tumor suppressor. A better understanding of the molecular basis of prostate cancer may permit a more accurate assessment of this disease.

\section{Compliance with ethical standards}

Conflict of interest None.

Open Access This article is distributed under the terms of the Creative Commons Attribution 4.0 International License (http://crea tivecommons.org/licenses/by/4.0/), which permits unrestricted use, distribution, and reproduction in any medium, provided you give appropriate credit to the original author(s) and the source, provide a link to the Creative Commons license, and indicate if changes were made.

\section{References}

1. Wojciechowska U, Didkowska J, Zatoński W. Cancer in Poland in 2012. Warsaw: Maria Sklodowska-Curie Memorial Cancer Center and Institute of Oncology, Polish National Cancer Registry; 2014.

2. Andreoiu M, Cheng L. Multifocal prostate cancer: biologic, prognostic, and therapeutic implications. Hum Pathol. 2010;41:781-93.

3. Madu CO, Lu Y. Novel diagnostic biomarkers for prostate cancer. J Cancer. 2010;1:150-77.

4. Bjartell A, Montironi R, Berney DM, Egevad L. Tumour markers in prostate cancer II: diagnostic and prognostic cellular biomarkers. Acta Oncol. 2011;50:76-84.

5. Shariat SF, Semjonow A, Lilja H, Savage C, Vickers AJ, Bjartell A. Tumor markers in prostate cancer I: blood-based markers. Acta Oncol. 2011;1:61-75.

6. Verma M, Patel P, Verma M. Biomarkers in prostate cancer epidemiology. Cancers. 2011;3:3773-98.

7. Choudhury AD, Eeles R, Freedland SJ, Isaacs WB, Pomerantz MM, Schalken JA, Tammela TL, Visakorpi T. The role of genetic markers in the management of prostate cancer. Eur Urol. 2012;62:577-87.

8. Willard SS, Koochekpour S. Regulators of gene expression as biomarkers for prostate cancer. Am J Cancer Res. 2012;2:620-57.

9. Goh CL, Schumacher FR, Easton D, Muir K, Henderson B, KoteJarai Z, Eeles RA. Genetic variants associated with predisposition to prostate cancer and potential clinical implications. J Intern Med. 2012;271:353-65.

10. Nakagawa H, Akamatsu S, Takata R, Takahashi A, Kubo M, Nakamura Y. Prostate cancer genomics, biology, and risk assessment through genome-wide association studies. Cancer Sci. 2012;103:607-13.
11. Dong $\mathrm{X}$, Wang L, Taniguchi K, Wang X, Cunningham JM, McDonnell SK, Qian C, Marks AF, Slager SL, Peterson BJ, Smith DI, Cheville JC, Blute ML, Jacobsen SJ, Schaid DJ, Tindall DJ, Thibodeau SN, Liu W. Mutations in CHEK2 associated with prostate cancer risk. Am J Hum Genet. 2003;72:270-80.

12. Edwards SM, Kote-Jarai Z, Meitz J. Two percent of men with early-onset prostate cancer harbor germline mutations in the BRCA2 gene. Am J Hum Genet. 2003;72:1-12.

13. Cybulski C, Górski B, Dębniak T, Gliniewicz B, Mierzejewski M, Masojć B, Jakubowska A, Matyjasik J, Złowocka E, Sikorski A, Narod SA, Lubiński J. NBS1 is a prostate cancer susceptibility gene. Cancer Res. 2004;64:1215-9.

14. Cybulski C, Górski B, Huzarski T, Masojć B, Mierzejewski M, Dębniak T, Teodorczyk U, Byrski T, Gronwald J, Matyjasik J, Zlowocka E, Lenner M, Grabowska E, Nej K, Castaneda J, Medrek K, Szymańska A, Szymańska J, Kurzawski G, Suchy J, Oszurek O, Witek A, Narod SA, Lubiński J. CHEK2 is a multiorgan cancer susceptibility gene. Am J Hum Genet. 2004;75:1131-5.

15. Agalliu I, Karlins E, Kwon EM, Iwasaki LM, Diamond A, Ostrander EA, Stanford JL. Rare germline mutations in the BRCA2 gene are associated with early-onset prostate cancer. Br J Cancer. 2007;97:826-31.

16. Cybulski C, Górski B, Gronwald J, Huzarski T, Byrski T, Dębniak T, Jakubowska A, Wokołorczyk D, Gliniewicz B, Sikorski A, Stawicka M, Godlewski D, Kwias Z, Antczak A, Krajka K, Lauer W, Sosnowski M, Sikorska-Radek P, Bar K, Klijer R, Romuald Z, Małkiewicz B, Borkowski A, Borkowski T, Szwiec M, Posmyk M, Narod SA, Lubiński J. BRCA1 mutations and prostate cancer in Poland. Eur J Cancer Prev. 2008;17:62-6.

17. Grindedal EM, Møller P, Eeles R, Stormorken AT, Bowitz-Lothe IM, Landrø SM, Clark N, Kvåle R, Shanley S, Maehle L. Germline mutations in mismatch repair genes associated with prostate cancer. Cancer Epidemiol Biomarkers Prev. 2009;18:2460-7.

18. Kote-Jarai Z, Jugurnauth S, Mulholland S. A recurrent truncating germline mutation in the BRIP1/FANCJ gene and susceptibility to prostate cancer. Br J Cancer. 2009;100:426-30.

19. Langeberg WJ, Kwon EM, Koopmeiners JS. Population-based study of the association of variants in mismatch repair genes with prostate cancer risk and outcomes. Cancer Epidemiol Biomarkers Prev. 2010;19:258-64.

20. Bansal A, Soni A, Rao P, Singh LC, Mishra AK, Mohanty NK, Saxena S. Implication of DNA repair genes in prostate tumourigenesis in Indian males. Indian J Med Res. 2012;136:622-32.

21. Li X, Heyer WD. Homologous recombination in DNA repair and DNA damage tolerance. Cell Res. 2008;18:99-113.

22. San Filippo J, Sung P, Klein H. Mechanism of eukaryotic homologous recombination. Annu Rev Biochem. 2008;77:229-57.

23. Krejci L, Altmannova V, Spirek M, Zhao X. Homologous recombination and its regulation. Nucleic Acids Res. 2012;40:5795-818.

24. Heyer WD. Biochemistry of eukaryotic homologous recombination. Top Curr Genet. 2007;17:95-133.

25. Boutou E, Pappa V, Stuertzbecher HW, Constantinos EV. Structure-function relationship of DNA repair proteins: lessons from BRCA1 and RAD51 studies. In: Kruman I, editor. DNA Repair. Rijeka: InTech; 2011. p. 103-24.

26. Sundararajan S, Ahmed A, Goodman OB Jr. The relevance of BRCA genetics to prostate cancer pathogenesis and treatment. Clin Adv Hematol Oncol. 2011;9:748-55.

27. Castro E, Eeles R. The role of BRCA1 and BRCA2 in prostate cancer. Asian J Androl. 2012;14:409-14.

28. Cawkwell L, Bell SM, Lewis FA, Dixon MF, Taylor GR, Quirke P. Rapid detection of allele loss in colorectal tumours using microsatellites and fluorescent DNA technology. Br J Cancer. $1993 ; 67: 1262-7$ 
29. Ostrander EA, Udler MS. The role of the BRCA2 gene in susceptibility to prostate cancer revisited. Cancer Epidemiol Biomarkers Prev. 2008;17:1843-8.

30. Klein HL. The consequences of Rad51 overexpression for normal and tumor cells. DNA Repair (Amst). 2008;7:686-93.

31. Mitra A, Jameson C, Barbachano Y. Overexpression of RAD51 occurs in aggressive prostatic cancer. Histopathology. 2009;55:696-704.

32. Schild D, Wiese C. Overexpression of RAD51 suppresses recombination defects: a possible mechanism to reverse genomic instability. Nucleic Acids Res. 2010;38:1061-70.

33. Schwarzenbach H, Chun FK, Lange I. Detection of tumorspecific DNA in blood and bone marrow plasma from patients with prostate cancer. Int J Cancer. 2007;120:1465-71.

34. Sunami E, Shinozaki M, Higano CS, Wollman R, Dorff TB, Tucker SJ, Martinez SR, Mizuno R, Singer FR, Hoon DS. Multimarker circulating DNA assay for assessing blood of prostate cancer patients. Clin Chem. 2009;55:559-67.

35. Koochekpour S. Genetic and epigenetic changes in human prostate cancer. Iran Red Crescent Med J. 2011;13:80-98.

36. Breast Cancer Linkage Consortium. Cancer risks in BRCA2 mutation carriers. J Natl Cancer Inst. 1999;91:1310-6.

37. Edwards SM, Evans DG, Hope Q, Norman AR, Barbachano Y, Bullock S, Kote-Jarai Z, Meitz J, Falconer A, Osin P, Fisher C, Guy M, Jhavar SG, Hall AL, O'Brien LT, Gehr-Swain BN, Wilkinson RA, Forrest MS, Dearnaley DP, Ardern-Jones AT, Page EC, Easton DF, Eeles RA, UK Genetic Prostate Cancer Study Collaborators and BAUS Section of Oncology. Prostate cancer in BRCA2 germline mutation carriers is associated with poorer prognosis. Br J Cancer. 2010;103:918-24.
38. Kote-Jarai Z, Leongamornlert D, Saunders E, Tymrakiewicz M, Castro E, Mahmud N, Guy M, Edwards S, O'Brien L, Sawyer E, Hall A, Wilkinson R, Dadaev T, Goh C, Easton D, UKGPCS Collaborators, Goldgar D, Eeles R. BRCA2 is a moderate penetrance gene contributing to young-onset prostate cancer: implications for genetic testing in prostate cancer patients. $\mathrm{Br} \mathrm{J}$ Cancer. 2011;105:1230-4.

39. Leongamornlert D, Mahmud N, Tymrakiewicz M, Saunders E, Dadaev T, Castro E, Goh C, Govindasami K, Guy M, O'Brien L, Sawyer E, Hall A, Wilkinson R, Easton D, UKGPCS Collaborators, Goldgar D, Eeles R, Kote-Jarai Z. Germline BRCA1 mutations increase prostate cancer risk. $\mathrm{Br} \mathrm{J}$ Cancer. 2012;106:1697-701.

40. Uchida T, Wang C, Sato T, Gao J, Takashima R, Irie A, Ohori M, Koshiba K. BRCA1 gene mutation and loss of heterozygosity on chromosome $17 \mathrm{q} 21$ in primary prostate cancer. Int $\mathrm{J}$ Cancer. 1999;84:19-23.

41. Willems AJ, Dawson SJ, Samaratunga H, De Luca A, Antill YC, Hopper JL, Thorne HJ, kConFab Investigators. Loss of heterozygosity at the BRCA2 locus detected by multiplex ligation-dependent probe amplification is common in prostate cancers from men with a germline BRCA2 mutation. Clin Cancer Res. 2008;14:2953-61.

42. Willems-Jones A, Kavanagh L, Clouston D, Bolton D, kConFab Investigators, Fox S, Thorne H. High grade prostatic intraepithelial neoplasia does not display loss of heterozygosity at the mutation locus in BRCA2 mutation carriers with aggressive prostate cancer. BJU Int. 2012;110:E1181-6. 